\title{
AKTIVITAS ANTIOKSIDAN KOMBINASI EKSTRAK ETANOL DAUN JARONG (Stachytarpheta indica) DAN BATANG CENTE (Lantana camara)
}

\author{
ANTIOXIDANT ACTIVITIES OF COMBINATION ETHANOL \\ EXTRACTS OF INDIAN SNAKEWEED LEAF (Stachytarpheta indica) \\ AND LANTANA STEM (Lantana camara) \\ Eris Septiana $^{1 *}$, Nursifa Mawadah ${ }^{2}$, Partomuan Simanjuntak $^{3,4}$ \\ ${ }^{1}$ Puslit Bioteknologi LIPI \\ Jl. Raya Bogor km 46, Bogor \\ ${ }^{2}$ Departemen Kimia, Fakultas MIPA, IPB \\ Jl. Tanjung, Kampus IPB Dramaga, Bogor \\ ${ }^{3}$ Pusat Penelitian Kimia LIPI, \\ Jl. Puspitek serpong Gate, Muncul, Kec. Serpong, Kota Tangerang Selatan \\ ${ }^{4}$ Fakultas Farmasi, Universitas Pancasila \\ Jl. Srengseng Sawah, Jakarta \\ *Penulis Korespondensi, e-mail: septiana.eris@gmail.com
}

\begin{abstract}
ABSTRAK
Penggunaan tanaman obat sebagai sumber senyawa antioksidan semakin meningkat. Beberapa tanaman yang telah dilaporkan sebagai sumber senyawa antioksidan adalah daun jarong (Stachytarpheta indica) dan batang cente (Lantana camara). Namun, belum ada penelitian yang melaporkan kombinasi kedua tanaman tersebut sebagai sumber antioksidan. Oleh karena itu, penelitian ini bertujuan untuk mengetahui pengaruh kombinasi ekstrak etanol daun jarong dan batang cente terhadap aktivitas antioksidannya. Aktivitas antioksidan in vitro berdasarkan pada metode peredaman radikal bebas DPPH (2,2-diphenyl-1-picrylhydrazyl). Penapisan fitokimia dan analisis indeks kombinasi juga dilakukan untuk menentukan efek kombinasinya. Semua ekstrak etanol tunggal dan kombinasi menunjukkan aktivitas antioksidan. Kombinasi ekstrak etanol daun jarong dan batang cente dalam perbandingan 1:2 memberikan aktivitas antioksidan tertinggi dengan nilai $\mathrm{IC}_{50}$ sebesar $18,86 \mu \mathrm{g} / \mathrm{mL}$. Penapisan fitokimia menunjukkan bahwa senyawa steroid, tanin, flavonoid, dan fenolik ditemukan pada kedua ekstrak. Alkaloid, kuinon, dan saponin hanya ditemukan dalam ekstrak daun jarong. Sementara itu, kumarin hanya ditemukan dalam ekstrak batang cente. Kombinasi ekstrak etanol menunjukkan efek sinergis ringan-sedang sampai mendekati aditif dengan nilai CI antara 0,7723-0,9607. Oleh karena itu, kombinasi ekstrak dapat meningkatkan aktivitas antioksidannya.
\end{abstract}

Kata kunci: antioksidan, kombinasi ekstrak, Lantana camara, sinergis, Stachytarpheta indica 


\begin{abstract}
The use of medicinal plants as a source of antioxidant compounds is increasing. Some plants that have been reported as sources of antioxidant compounds are Indian snakeweed leaf (Stachytarpheta indica) and lantana stem (Lantana camara). However, there are no studies that report a combination of the two plants as a source of antioxidants. Therefore, this study aims to determine the effect of Indian snakeweed leaf and lantana stem ethanol extracts combination on their antioxidant activity. In vitro antioxidant activity based on the DPPH (2,2-diphenyl-1-picrylhydrazyl) free radical reduction method. Phytochemical screening, and combination index analysis were also carried out to determine the combined effect. All ethanol extracts of both single and combination plants showed antioxidant activity. The combination of Indian snakeweed leaf and lantana stem ethanol in a ratio of 1:2 gives the highest antioxidant activity with $I_{50}$ value at $18.86 \mu \mathrm{g} / \mathrm{mL}$. Phytochemical screening showed that the steroids, tannins, flavonoids, and phenolic compounds found in both extracts. The alkaloids, quinones, and saponins only found in the Indian snakeweed leave extract. Meanwhile, the coumarins only found in the lantana stem extract. The combination of ethanol extract shows mildmoderate synergistic to close to additives categories with CI values at 0.7723-0.9607. So that the combination of extracts can increase its antioxidant activity.
\end{abstract}

Keywords: antioxidant, combination extracts, Lantana camara, Stachytarpheta indica, synergistic

\title{
PENDAHULUAN
}

Pemanfaatan tumbuhan sebagai bahan obat sudah sejak lama dilakukan oleh masyarakat di Indonesia. Dengan keanekaragaman etnis yang ada, maka pemanfaatan sebagai obat juga semakin beraneka ragam (Rahayu et al., 2012). Tanaman yang berguna untuk pengobatan herbal diantaranya jarong atau pecut kuda (Stachytarpheta indica) dan cente atau tembelekan (Lantana camara). Tumbuhan jarong dikenal sebagai salah satu tumbuhan obat yang digunakan oleh sebagian masyarakat Asia dan Amerika sebagai obat haid tidak teratur, hepatitis, dan sakit tenggorokan. Daun jarong mengandung senyawa kimia berupa tannin, saponin, dan alkaloid (Sahoo et al., 2014). Cente merupakan tumbuhan asal Amerika, banyak ditemukan sebagai tumbuhan liar maupun ditanam sebagai tumbuhan hias taman atau pekarangan. Cente telah digunakan secara tradisional sebagai obat bengkak, rematik, keputihan, dan penurun panas. Senyawa kimia yang terkandung dalam cente yaitu flavonoid, alkaloid, tannin,saponin, glikosida, dan fitosterol (Tadesse et al., 2017). 
Antioksidan didefinisikan sebagai senyawa yang mampu menunda, memperlambat, atau menghambat reaksi oksidasi. Metode peredaman radikal bebas DPPH dapat mengukur kemampuan suatu senyawa antioksidan dalam meredam radikal bebas. Kemampuan peredaman radikal bebas berhubungan dengan kemampuan komponen senyawa dalam menyumbangkan elektron atau hidrogen (Dewanjee et al., 2015). Proses oksidasi ini akan melepaskan radikal-radikal bebas yang memiliki dampak dapat merusak sel-sel tubuh. Ketika menetralkan radikal-radikal bebas, senyawa antioksidan pada akhirnya juga akan mengalami proses oksidasi. Maka, tubuh sangat membutuhkan pasokan antioksidan secara terus menerus. Kerusakan yang disebabkan oleh adanya radikal bebas dalam waktu yang lama akan dapat memicu penyakit kanker. Untuk mencegah hal seperti ini, maka perlu adanya konsumsi antioksidan untuk dapat mengembalikan kerusakan-kerusakan yang disebabkan oleh adanya proses oksidasi hingga batas-batas tertentu (Aisyah and Rasdiansyah, 2015).

Antioksidan alami dapat ditemukan pada tumbuhan yang mengandung senyawa metabolit sekunder yang berpotensi sebagai antioksidan. Daun jarong dan batang cente merupakan tumbuhan yang terkenal mempunyai aktivitas sebagai antioksidan. Ekstrak metanol daun jarong telah dilaporkan memiliki aktivitas antioksidan yang lebih tinggi dibandingkan dengan bagian daunnya (Sahoo et al., 2014). Ekstrak metanol batang cente juga dilaporkan mempunyai aktivitas antioksidan yang kuat dengan nilai $\mathrm{IC}_{50}$ sebesar 46,96 $\mu \mathrm{g} / \mathrm{mL}$ (Mahdi-Pour et al., 2012). Selain uji aktivitas peredaman radikal bebas terhadap ekstrak tunggalnya, beberapa penelitian sebelumnya telah melakukan uji terhadap kombinasi dari dua jenis tanaman berkhasiat antioksidan yang berbeda. Aktivitas antioksidan dari tanaman obat dapat ditingkatkan salah satunya dengan melakukan kombinasi ekstrak. Kombinasi ekstrak daun cempedak Artocarpus champedan dan daun bandotan Ageratum conyzoides dapat meningkatkan aktivitas antioksidannya dibandingkan dengan masing-masing ekstrak tunggalnya (Halimatussa'diah et al., 2014). Berdasarkan informasi, masing-masing ekstrak tunggal daun jarong dan batang cente memiliki aktivitas antioksidan dan kombinasi ekstrak dapat meningkatkan aktivitas antioksidannya. Ditambah lagi belum ada penelitian yang melakukan kombinasi ekstrak daun jarong dan batang cente untuk meningkatkan aktivitas 
antioksidannya. Oleh karena itu, dari latar belakang tersebut, penelitian ini bertujuan untuk mengetahui pengaruh kombinasi ekstrak daun jarong dan batang cente terhadap aktivitas antioksidannya melalui peredaman radikal bebas DPPH.

\section{METODE PENELITIAN}

Alat dan Bahan

Bahan yang digunakan dalam penelitian ini adalah koleksi simplisia Laboratorium Kimia Bahan Alam, P2 Biotekologi LIPI yaitu daun tanaman jarong (Stachytarpheta indica) nomor koleksi OT98030D dan batang tanaman cente (Lantana camara) nomor koleksi OT98021B. Kedua simplisia tanaman dikoleksi dari Sukabumi, Jawa Barat. DPPH (2,2-diphenyl-1-picrylhydrazyl) (Sigma), asam askorbat (Sigma), $\mathrm{NH}_{4} \mathrm{OH}$ (Merck), $\mathrm{HCl}$ (Merck), asam asetat glasial (Merck), $\mathrm{H}_{2} \mathrm{SO}_{4}$ (Merck), $\mathrm{NH}_{3}$ (Merck), $\mathrm{NaOH}$ (Merck), $\mathrm{FeCl}_{3}$ (Merck), serbuk $\mathrm{Mg}$ (Merck), amil alkohol (Merck), metanol pro analisis (Merck), pereaksi Dragendorf, dan pelarut teknis kloroform, eter, dan etanol.

Alat yang digunakan dalam penelitian ini adalah spektrofotometer UV-Vis (Hitachi-U3900) dan peralatan penunjang lainnya.

\section{Jalannya Penelitian}

Ekstraksi

Simplisia tanaman daun jarong (DJ) dan batang cente (BC) merupakan koleksi Laboratorium Kimia Bahan Alam, Puslit Bioteknologi, LIPI yang sebelumnya telah dideterminasi di Herbarium Bogoriense, Puslit Biologi, LIPI. Sebanyak masing-masing $100 \mathrm{~g}$ simplisia dimaserasi dengan $800 \mathrm{~mL}$ etanol $96 \%$ pada suhu ruang selama 24 jam. Setelah 24 jam, maserat dipisahkan kemudian residu dimaserasi kembali dengan jenis dan jumlah pelarut yang sama sebanyak tiga kali ulangan. Semua maserat dikumpulkan dan dipekatkan dengan penguap putar hampa udara. Bobot ekstrak kering yang diperoleh kemudian ditimbang. Rendemen ekstrak dihitung dengan membandingkan bobot ekstrak yang diperoleh terhadap bobot sampel awal. Setelah didapatkan ekstrak tunggal, maka dibuat kombinasi ekstrak dengan kombinasi 1:1, 1:2, dan 2:1 (satu bagian kombinasi setara dengan $1 \mathrm{~g}$ ekstrak). 
Uji aktivitas antioksidan

Uji aktivitas antioksidan dilakukan menggunakan metode peredaman radikal bebas senyawa DPPH (Vankar et al., 2006) dengan modifikasi pada panjang gelombang dari $515 \mathrm{~nm}$ menjadi $517 \mathrm{~nm}$. Konsentrasi larutan uji ekstrak etanol 96\% daun jarong dan batang cente dalam metanol sebesar 2,5; 5; 10; 20; dan $40 \mu \mathrm{g} / \mathrm{mL}$. Konsentrasi asam askorbat (vitamin C) sebagai kontrol positif sebesar 1, 2, 3, 4, dan $5 \mu \mathrm{g} / \mathrm{mL}$ serta DPPH 0,4 mM sebagai blanko. Seluruh sampel larutan uji, kontrol positif, dan blanko diinkubasi pada suhu $37^{\circ} \mathrm{C}$ selama 30 menit. Serapan seluruh sampel, kontrol positif, dan blanko kemudian diukur pada panjang gelombang $517 \mathrm{~nm}$. Aktivitas antioksidan didapatkan dengan menggunakan persamaan 1 .

$$
\% \text { Hambat }=\frac{\mathrm{A}-\mathrm{B}}{\mathrm{A}} \times 100 \%
$$

Keterangan:

$\mathrm{A}=$ serapan blanko

$\mathrm{B}=$ serapan sampel

Penapisan fitokimia

Penapisan fitokimia secara kualitatif meliputi uji alkaloid, steroid/triterpenoid, kumarin, flavonoid, kuinon, saponin, dan tannin (Harborne, 1998). Uji alkaloid dilakukan dengan melembabkan sampel dengan $\mathrm{NH}_{4} \mathrm{OH} 25 \%$ kemudian ditambahkan kloroform. Filtrat berupa larutan organik (lapisan kloroform) diekstraksi dengan $\mathrm{HCl}$ pekat. Lapisan asam diambil dan kemudian ditambah beberapa tetes pereaksi Dragendorff. Terbentuknya endapan merah bata setelah penambahan pereaksi Dragendorff menunjukkan adanya alkaloid. Uji steroid/triterpenoid : sampel direndam dalam eter selama 2 jam, lalu disaring. Filtrat kemudian diuapkan dan ditambahkan pereaksi Liebermann-Burchard (2 tetes asam asetat glasial dan 1 tetes asam sulfat pekat) pada residu. Terbentuknya warna merah, hijau ungu dan akhirnya biru menunjukkan adanya steroid/triterpenoid. Uji kumarin dilakukan dengan cara sampel direndam dalam eter, kemudian disaring dan diuapkan. Setelah kering, residu ditambahkan air panas dan 
didinginkan. Setelah dingin ditambahkan larutan amoniak 10\%. Adanya fluoresensi hijau atau biru pada sinar UV menunjukkan adanya kumarin

Pada uji flavonoid, saponin, tanin dan kuinon, sampel dididihkan dalam air panas selama 5 menit, kemudian dibagi ke dalam 4 tabung reaksi. Tabung pertama ditambahkan dengan serbuk magnesium, $\mathrm{HCl}$ pekat dan amil alkohol. Dikocok dengan kuat dan dibiarkan memisah. Adanya flavonoid ditunjukkan dengan terbentuknya warna merah, kuning atau jingga pada lapisan alkohol. Tabung kedua dikocok kuat secara vertikal hingga terbentuk busa. Jika busa masih ada setelah didiamkan 10 menit dan setelah penambahan $\mathrm{HCl} 2 \mathrm{~N}$, maka sampel mengandung saponin. Tabung ketiga ditambahkan larutan $\mathrm{FeCl}_{3} 1 \%$. Timbulnya warna hijau biru menunjukkan adanya kandungan tanin. Tabung keempat ditambahkan dengan $\mathrm{NaOH}$ 1N. Terbentuknya warna merah menunjukkan adanya kuinon. Identifikasi adanya senyawa fenolik dalam suatu cuplikan dapat dilakukan dengan pereaksi besi (III) klorida $\left(\mathrm{FeCl}_{3}\right) 1 \%$ dalam etanol. Adanya senyawa fenolik ditunjukkan oleh timbulnya warna hijau, merah, ungu, biru, atau, hitam yang kuat.

Analisis kombinasi ekstrak

Aktivitas peredaman radikal bebas kombinasi ekstrak ditetapkan dengan menghitung indeks kombinasi (Chou, 2006) antara ekstrak daun jarong dan batang cente menggunakan persamaan 2 .

Combination Index $(\mathrm{CI})=\frac{\mathrm{D} 1}{(\mathrm{Dx}) 1}+\frac{\mathrm{D} 2}{(\mathrm{Dx}) 2}$

Dimana (Dx)1 dan (Dx)2 adalah konsentrasi dari satu ekstrak tunggal yang dibutuhkan untuk memberikan efek (dalam hal ini adalah $\mathrm{IC}_{50}$ terhadap aktivitas peredaman radikal bebas), sedangkan D1, dan D2 adalah besarnya konsentrasi kedua ekstrak (kombinasi) untuk memberikan efek yang sama. Angka CI atau Combination Index yang diperoleh diinterpretasikan sebagai berikut: $<0,1$ sinergis sangat kuat; $0,1-0,3$ sinergis kuat; 0,3-0,7 sinergis; 0,7-0,9 sinergis ringan-sedang; 0,9-1,1 mendekati aditif; 
1,1-1,45 antagonis ringan-sedang; 1,45-3,3 antagonis; >3,3 antagonis kuat-sangat kuat (Reynolds and Maurer, 2005).

\section{HASIL DAN PEMBAHASAN}

Ekstraksi

Ekstraksi merupakan langkah awal yang dilakukan sebagai bagian dari persiapan sampel untuk digunakan dalam berbagai uji berikutnya. Ekstraksi daun jarong dan batang cente dilakukan dengan menggunakan metode maserasi, yaitu proses mengekstrak simplisia dengan menggunakan pelarut melalui beberapa pengocokan pada suhu ruang untuk simplisia yang mengandung senyawa aktif yang mudah larut (Lumbessy et al., 2013). Prinsip ekstraksi didasarkan pada perpindahan massa komponen zat padat ke dalam pelarut dimana perpindahan mulai terjadi pada lapisan antar muka, kemudian berdifusi masuk ke dalam pelarut (Nurhasnawati et al., 2017).

Rendemen merupakan perbandingan jumlah (kuantitas) ekstrak yang dihasilkan dari ekstraksi tanaman: yaitu yang terdapat pada sampel daun jarong dan batang cente yang terekstrak dari pelarut yang digunakan. Kuantitas rendemen dapat digunakan untuk mengetahui kemampuan pelarut dalam memisahkan senyawa aktif yang terdapat pada simplisia yang digunakan (Razak et al., 2012). Hasil ekstrak dari daun jarong dengan warna hijau tua memiliki rendemen sebesar 13,3\%, sedangkan hasil ekstrak dari batang cente dengan warna cokelat kemerah-merahan memiliki rendemen sebesar 4,12\% dari berat sampel kering mula-mula. Hasil ini menunjukkan bahwa ekstraksi dengan pelarut etanol ini dapat menarik senyawa metabolit sekunder dalam daun jarong dan batang cente dengan cukup baik.

\section{Aktivitas antioksidan}

Hasil pengujian aktivitas antioksidan menunjukkan bahwa seluruh ekstrak tanaman uji baik berupa ekstrak tunggal maupun kombinasinya memiliki aktivitas peredaman radikal bebas DPPH (Tabel I). Pada konsentrasi tertinggi yaitu $40 \mu \mathrm{g} / \mathrm{mL}$, persentase penghambatan bervariasi antara 77,9 - 86,4 \%. Ekstrak etanol 96\% daun jarong merupakan ekstrak dengan penghambatan terendah sedangkan ekstrak etanol $96 \%$ 
kombinasi DJ-BC 1:1 dan 1:2 merupakan ekstrak dengan aktivitas tertinggi dibandingkan dengan ekstrak lainnya pada konsentrasi tertinggi. Radikal bebas adalah substansi yang berbahaya yang sangat reaktif sehingga dapat merusak jaringan organ-organ tubuh hingga menimbulkan berbagai penyakit. Uji antioksidan ekstrak daun jarong, batang cente serta kombinasi ekstrak menggunakan metode peredaman radikal bebas DPPH (1,1-diphenyl2-picrylhydrazyl). Larutan DPPH akan bereaksi dengan antioksidan alami yang menyebabkan warna ungu DPPH akan berubah menjadi warna kuning. Semakin tinggi kandungan antioksidan maka warna ungu pada larutan DPPH akan semakin muda dan akan membentuk warna kunin (Purwaningsih, 2012).

Tabel I. Analisis aktivitas peredaman radikal bebas kombinasi ektrak etanol 96\% daun jarong (DJ) dan batang cente (BC) dengan perbandingan 1:1, 1:2, dan 2:1 beserta pengujian ekstrak tunggalnya

\begin{tabular}{ccccccc}
\hline \multirow{2}{*}{ No. } & $\begin{array}{c}\text { Konsentrasi } \\
(\boldsymbol{\mu g} / \mathbf{m L})\end{array}$ & $\begin{array}{c}\text { DJ } \\
\text { (tunggal) }\end{array}$ & $\begin{array}{c}\text { BC } \\
\text { (tunggal) }\end{array}$ & $\begin{array}{c}\text { DJ - BC } \\
(\mathbf{1 : 1})\end{array}$ & $\begin{array}{c}\text { DJ - BC } \\
(\mathbf{1 : 2})\end{array}$ & $\begin{array}{c}\text { DJ - BC } \\
(\mathbf{2 : 1})\end{array}$ \\
\hline 1 & 2,5 & 1,38 & 0,50 & 8,81 & 5,28 & 0,75 \\
2 & 5 & 17,23 & 3,77 & 19,25 & 20,38 & 4,03 \\
3 & 10 & 21,38 & 19,62 & 39,25 & 41,64 & 19,62 \\
4 & 20 & 37,48 & 42,26 & 52,83 & 51,70 & 43,52 \\
5 & 40 & 77,9 & 85,66 & 86,04 & 85,53 & 86,04 \\
\hline
\end{tabular}

Nilai IC $_{50}$ diketahui dari persen aktivitas antioksidan dari ekstrak daun jarong dan batang cente. Nilai $\mathrm{IC}_{50}$ adalah konsentrasi yang diperlukan untuk mereduksi DPPH sebesar 50\%. Nilai $\mathrm{IC}_{50}$ dapat ditetapkan dengan persamaan regresi linier. Semakin kecil nilai IC $_{50}$ yang didapat maka semakin tinggi kekuatan suatu senyawa yang bersifat antioksidan untuk melawan senyawa DPPH sebagai radikal bebas (Rosahdi et al., 2015). Kekuatan aktivitas antioksidan dapat dikelompokkan ke dalam kategori sangat aktif jika memiliki $\mathrm{IC}_{50}<10 \mu \mathrm{g} / \mathrm{mL}$, aktif jika memiliki $\mathrm{IC}_{50}<100 \mu \mathrm{g} / \mathrm{mL}$, dan tidak aktif jika memiliki $\mathrm{IC}_{50}>100 \mu \mathrm{g} / \mathrm{mL}$ (Minami et al., 1994). Secara keseluruhan, aktivitas antioksidan seluruh ekstrak etanol $96 \%$ daun jarong dan batang cente baik ekstrak tunggal maupun kombinasi masuk dalam kategori aktif karena nilai $\mathrm{IC}_{50}<100 \mu \mathrm{g} / \mathrm{mL}$ namun masih dibawah kontrol positif yaitu vitamin $\mathrm{C}$ (asam askorbat) yang memiliki nilai $\mathrm{IC}_{50}$ sebesar 3,05 $\mu \mathrm{g} / \mathrm{mL}$ dengan kategori sangat aktif (Tabel II). Aktivitas antioksidan ekstrak 
etanol $96 \%$ daun jarong dan batang cente pada kombinasi 1:2 merupakan yang paling tinggi dibandingkan dengan ekstrak lainnya dengan nilai $\mathrm{IC}_{50}$ sebesar $18,86 \mu \mathrm{g} / \mathrm{mL}$.

Tabel II. Nilai $\mathrm{IC}_{50}$ dari pengujian peredaman radikal bebas ekstrak tunggal dan kombinasi ekstrak daun jarong dan batang cente

\begin{tabular}{cc}
\hline Larutan uji & IC $_{\mathbf{5 0}}(\boldsymbol{\mu \mathbf { g }} / \mathbf{m L})$ \\
\hline Ekstrak etanol 96\% DJ (tunggal) & 25,20 \\
Ekstrak etanol 96\% BC (tunggal) & 24,05 \\
Ekstrak etanol 96\% DJ - BC (1:1) & 19,12 \\
Ekstrak etanol 96\% DJ - BC (1:2) & 18,86 \\
Ekstrak etanol 96\% DJ - BC (2:1) & 23,83 \\
Vitamin C & 3,05 \\
\hline
\end{tabular}

Penapisan fitokimia

Analisis fitokimia secara kualitatif dilakukan terhadap ekstrak daun jarong dan batang cente untuk mengetahui komponen metabolit sekunder yang terkandung dalam ekstrak. Uji fitokima meliputi keberadaan alkaloid, flavonoid, tanin, saponin, steroid, triterpenoid, dan senyawa fenolik. Senyawa fitokimia yang terkandung sebagian besar dapat berperan sebagai antioksidan (Yang et al., 2010). Menurut literatur, kandungan metabolit sekunder dari daun jarong di antaranya ialah senyawa tannin, saponin, dan alkaloid (Sahoo et al., 2014). Metabolit sekunder dari batang cente di antaranya ialah flavonoid, alkaloid, tannin, saponin, glikosida, dan fitosterol (Tadesse et al., 2017). Beberapa senyawa yang termasuk dalam kelompok fenolik seperti fenol sederhana, flavonoid, dan tanin memiliki aktivitas antioksidan yang tinggi (Chiorcea-Paquim et al., 2020). 
Tabel III. Kandungan fitokimia ekstrak daun jarong dan batang cente

\begin{tabular}{ccc}
\hline \multirow{2}{*}{ Jenis Uji } & \multicolumn{2}{c}{ Hasil Pengamatan } \\
\cline { 2 - 3 } & Daun Jarong & Batang Cente \\
\hline Alkaloid & Positif & Negatif \\
Steroid & Positif & Positif \\
Kuinon & Positif & Negatif \\
Tanin & Positif & Positif \\
Flavonoid & Positif & Positif \\
Saponin & Positif & Negatif \\
Kumarin & Negatif & Positif \\
Senyawa Fenolik & Positif & Positif
\end{tabular}

Komponen bioaktif dalam suatu ekstrak tanaman obat berhubungan dengan aktivitas biologisnya. Ekstrak etanol 96\% daun jarong dan batang cente mengandung beberapa golongan senyawa kimia (Tabel III) yang berperan dalam meredam radikal bebas. Beberapa penelitian telah melaporkan bahwa komponen senyawa kimia yang terdeteksi pada pengujian penapisan fitokimia ini memiliki aktivitas antioksidan. Senyawa golongan flavonoid dilaporkan memiliki aktivitas antioksidan dengan cara mendonorkan satu elektron dari gugus $\mathrm{OH}$ fenoliknya ke radikal bebas untuk menstabilkan kembali senyawa radikal bebas (Bernatoniene and Kopustinskiene, 2018). Alkaloid dilaporkan memiliki aktivitas antioksidan melalui aktivitas peredaman radikal bebas (Tiong et al., 2013) dengan cara menyumbangkan elektron kepada senyawa radikal bebas (Zahari et al., 2016).

Saponin merupakan senyawa yang memiliki aktivitas peredaman radikal bebas yang sangat kuat (Chen et al., 2014). Steroid juga memiliki aktivitas antioksidan dengan meredam radikal bebas melalui donor atom hirogen (Koduru et al., 2007). Kuinon dan kumarin juga telah dilaporkan memiliki aktivitas antioksidan. Aktivitas antioksidan kedua senyawa ini berhubungan dengan jumlah dan posisi dari gugus hidroksil yang dimiliki (Jiang et al., 2015). Senyawa fenolik, termasuk juga tannin, mempunyai aktivitas antioksidan dengan meredam gugus $\mathrm{OH}$ pada senyawa radikal bebas (Gülçin et al., 2010). 
Analisis kombinasi ekstrak

Ekstrak tunggal daun jarong dan batang cente memiliki aktivitas antioksidan melalui peredaman radikal bebas yang cukup baik. Kemampuan sebagai antioksidan dari kedua ekstrak tanaman tersebut masih dapat ditingkatkan, salah satunya dengan melakukan kombinasi ekstrak diantara keduanya. Pada penelitian ini, kombinasi ekstrak etanol 96\% menghasilkan nilai $\mathrm{IC}_{50}$ yang lebih rendah dibandingkan dengan masingmasing ekstrak tunggalnya (Tabel IV). Hal ini menunjukkan bahwa kombinasi tesebut menunjukkan efek sinergis. Hasil ini sejalan dengan penelitian sebelumnya melaporkan bahwa kombinasi ekstrak dua tanaman dapat meningkatkan aktivitas antioksidannya (Halimatussa'diah et al., 2014). Efek sinergis ekstrak dapat didefinisikan bahwa efek biologis dari kombinasi yang dihasilkan lebih tinggi dari efek biologis ekstrak dalam bentuk tunggalnya (Roell et al., 2017).

Tabel IV. Nilai indeks kombinasi ekstrak etanol $96 \%$ daun jarong dan batang cente pada peredaman radikal bebas

\begin{tabular}{ccc}
\hline Ekstrak etanol 96\% DJ-BC & Nilai CI & Keterangan \\
\hline $1: 1$ & 0,7769 & Sinergis ringan-sedang \\
$1: 2$ & 0,7723 & Sinergis ringan-sedang \\
$2: 1$ & 0,9607 & Mendekati aditif \\
\hline
\end{tabular}

Selain menghasilkan efek sinergis, kombinasi ekstrak juga dapat menghasilkan efek kombinasi aditif maupun antagonis. Pada penelitian ini, kombinasi ekstrak etanol $96 \%$ pada perbandingan 2:1 menghasilkan efek kombinasi mendekati aditif. Efek aditif terjadi jika kombinasi ekstrak hanya memiliki pengaruh peningkatan biologisnya dari salah satu ekstrak tunggalnya (Vinholes and Vizzotto, 2016). Efek kombinasi aditif juga terjadi pada penelitian sebelumnya yang dilakukan oleh (Marianne et al., 2018) yang melaporkan bahwa kombinasi ekstrak etanol rimpang Curcuma heyneana dan daun Curanga felterrae dengan perbandingan 1:1 memiliki sifat aditif dalam aktivitas antioksidannya dengan nilai CI sebesar 1,09. 


\section{KESIMPULAN}

Daun jarong, batang cente, dan kombinasi ekstrak dari kedua tanaman tersebut memiliki aktivitas antioksidan melalui peredaman radikal bebas DPPH. Aktivitas antioksidan paling tinggi terdapat pada kombinasi ekstrak daun jarong-batang cente pada perbandingan 1:2 dengan nilai $\mathrm{IC}_{50}$ sebesar $18,86 \mu \mathrm{g} / \mathrm{mL}$. Kombinasi ekstrak dapat meningkatkan aktivitas antioksidan ekstrak tunggalnya.

\section{UCAPAN TERIMAKASIH}

Penulis mengucapkan terima kasih kepada Laboratorium Kimia Bahan Alam, P2 Bioteknologi LIPI atas akses koleksi simplisia tanaman obat, Dr. Eti Rohaeti, MS sebagai pembimbing lapang penulis kedua, dan Yadi sebagai teknisi laboratorium.

\section{DAFTAR PUSTAKA}

Aisyah, Y., \& Rasdiansyah Rasdiansyah, M. M. (2015). Pengaruh pemanasan terhadap aktivitas antioksidan pada beberapa jenis sayuran. Jurnal Teknologi Dan Industri Pertanian Indonesia, 6(2), 28-32.

Bernatoniene, J., \& Kopustinskiene, D. M. (2018). The role of catechins in cellular responses to oxidative stress. Molecules, 23(4), 965.

Chen, Y., Miao, Y., Huang, L., Li, J., Sun, H., Zhao, Y., Yang, J., \& Zhou, W. (2014). Antioxidant activities of saponins extracted from radix trichosanthis: an in vivo and in vitro evaluation. BMC Complement Alternative Medicine, 14(86), 1-8.

Chiorcea-Paquim, A., Enache, T. A., Gil Souza De, E., \& Oliveira-Brett, A. M. (2020). Natural phenolic antioxidants electrochemistry: towards a new food science methodology. Comprehensive Reviews In Food Science And Food Safety, 19, 16801726.

Dewanjee, S., Gangopadhyay, M., Bhattacharya, N., Khanra, R., \& K.Dua, T. (2015). Bioautography and its scope in the field of natural product chemistry. Journal of Pharmaceutical Analysis, 5(2), 75-84. 
Gülçin, İ., Huyut, Z., Elmastaş, M., \& Y.Aboul-Enein, H. (2010). Radical scavenging and antioxidant activity of tannic acid. Arabian Journal of Chemistry, 3(1), 43-53.

Halimatussa'diah, F., Fitriani, V. Y., \& Rijai, L. (2014). Aktivitas antioksidan kombinasi daun cempedak (Artocarpus champedan) dan daun bandotan (Ageratum conyzoides L). Journal of Tropical Pharmacy and Chemistry, 2(5), 248-251.

Harborne, J. B., (1998). Phytochemical methods: a guide to modern techniques of plant analysis, 3rd ed, Chapman \& Hall: London, UK. 1-32

Jiang, C., Wang, Q., Wei, Y. J., Yao, N., Wu, Z., Ma, Y., Lin, Z., Zhao, M., Che, C., Yao, X., Zhang, J., \& Yin, Z. (2015). Cholesterol-lowering effects and potential mechanisms of different polar extracts from Cyclocarya paliurus leave in hyperlipidemic mice. Journal of Ethnopharmacology, 176, 17-26. https://doi.org/10.1016/j.jep.2015.10.006

Koduru, S., Jimoh, F. O., Grierson, D. S., \& Afolayan, A. J. (2007). Antioxidant activity of two steroid alkaloids extracted from Solanum aculeastrum,. Journal of Pharmacology and Toxicology, 2(2), 160-167.

Lumbessy, M., Abidjulu, J., \& Paendong, J. J. E. (2013). Total flavonoid pada beberapa tanaman obat tradisional di desa Waitina Kecamatan Mangoli Timur Kabupaten Kepulauan Sula Provinsi Maluku Utara. Jurnal MIPA UNSRAT, 5(1), 50-55.

Mahdi-Pour, B., Jothy, S. L., Latha, L. Y., Chen, Y., \& Sasidharan, S. (2012). Antioxidant Activity of Methanol Extracts of Different Parts of Lantana camara, Asian Pac. Asian Pac J Trop Biomed, 2(12), 960-965.

Marianne, M., Patilaya, P., \& Barus, B. T. (2018). Uji aktivitas antioksidan kombinasi ekstrak etanol rimpang temu giring (Curcuma heyneana) dan daun pugun tanoh 
(Curanga fel-terrae) menggunakan Metode Diphenyl Picrylhydrazil (DPPH),. Talenta Conference Series: Tropical Medicine, 2(1), 398-404.

Minami, H., Kinoshita, M., Fukuyama, Y., Kodama, M., Yoshizawa, T., Sugiura, M., Nakagawa, K., \& Tago, H. (1994). Antioxidant xanthones from Garcinia subelliptica,. Phytochemistry, 36(2), 501-506.

Nurhasnawati, H., Sukarmi, S., \& Fitri Handayani. (2017). Perbandingan metode ekstraksi maserasi dan sokletasi terhadap aktivitas antioksidan ekstrak etanol daun jambu bol (Syzygium malaccense L.). Jurnal Ilmiah Manuntung, 3(1), 91-95.

Purwaningsih, S. (2012). Aktivitas antioksidan dan komposisi kimia keong matah merah (Cerithidea obtuse). Ilmu Kelautan, 17(1), 39-48.

Rahayu, M., Susiarti, S., \& Sihotang, V. B. L. (2012). A preliminary ethnobotanical study on useful plants by local communities in bodogol lowland forest, Sukabumi, West Java. Journal of Tropical Biology and Conservation, 9(1), 115-125.

Razak, M. F. B. A., Yong, P. K., Shah, Z. M., Abdullah, L. C., Yee, S. S., \& Yaw, I. T. C. S. (2012). The effects of varying solvent polarity on extraction yield of Orthosiphon stamineus leaves. Journal of Applied Sciences, 12(11), 1207-1210.

Reynolds, C. P., \& Maurer, B. J. (2005). Evaluating response to antineoplastic drug combinations in tissue culture models. Methods Mol Med, 110, 173-183.

Roell, K. R., Reif, D. M., \& Motsinger-Reif, A. A. (2017). An Introduction to terminology and methodology of chemical Synergy-Perspectives from Across Disciplines. Front Pharmacol, 8, 158.

Rosahdi, ina D., Susanti, Y., \& Suhendar, D. (2015). Uji aktivitas daya antioksidan 
biopigmen pada fraksi aseton dari mikroalga Chlorella vulgaris. Jurnal Istek, 9(1), $1-16$.

Sahoo, S. R., Dash, R. R., \& Bhatnagar, S. (2014). Phytochemical Screening and Bioevaluation of Medicinal Plant Stachytarpheta indica (L.) Vahl. Pharmacology \& Toxicology Research, 1(2), 1-5.

Tadesse, E., Engidawork, E., Nedi, T., \& Mengistu, G. (2017). Evaluation of the antidiarrheal activity of the aqueous stem extract of Lantana camara Linn (Verbenaceae) in mice. BMC Complementary and Alternative Medicine, 17(90), 18.

Tiong, S. H., Looi, C. Y., Hazni, H., Arya, A., Paydar, M., Wong, W. F., Cheah, S.-C., Mustafa, M. R., \& Awang, K. (2013). Antidiabetic and antioxidant properties of alkaloids from Catharanthus roseus (L.) G. Don. Molecules, 18(8), 9770-9784.

Vankar, P. S., Tiwari, V., Singh, L. W., \& Swapana, N. (2006). Antioxidant properties of some exclusive species of Zingiberaceae family of Manipur. Electronic Journal of Some Exclusive Species of Zingiberaceae Family of Manipur, 5(2), 1318-1322.

Vinholes, J., \& Vizzotto, M. (2016). Synergisms in Alpha-glucosidase inhibition and antioxidant activity of Camellia sinensis L. Kuntze and Eugenia uniflora L. Ethanolic Extracts. Pharmacognosy Res, 9(1), 101-107.

Yang, X., Yang, L., \& Zheng, H. (2010). Hypolipidemic and aantioxidant effects of Mulberry morusaiba L.) fruit in hyperlipidaemia rats. Food Chem Toxicol, 48(8-9), 2374-2379.

Zahari, A., Ablat, A., Sivasothy, Y., Mohamad, J., Choudhary, M. I., \& Awang, K. (2016). In vitro antiplasmodial and antioxidant activities of bisbenzylisoquinoline 
alkaloids from alseodaphne corneri kosterm. Asian Pacific Journal of Tropical Medicine, 9(4), 328-332. 